Каталізоване лакказою Trametes versicolor окиснення 7,8-дигідрокси-4-гідроксиметилкумарину / К. М. Лаховець, О. С. Цяпало, Ю. О. Лесишина, М.С. Фрасинюк, О. М. Шендрик // Вісник Донецького національного університету імені Василя Стуса. Серія хімічні науки. 2017. № 1. С. 38-43

УДК 577.152.113

\title{
КАТАЛІЗОВАНЕ ЛАККАЗОЮ TRAMETES VERSICOLOR ОКИСНЕННЯ 7,8-ДИГІДРОКСИ-4-ГІДРОКСИМЕТИЛКУМАРИНУ
}

\author{
К. М. Лаховець ${ }^{\text {a }, ~ О . ~ С . ~ Ц я п а л о ~}{ }^{\text {a }}{ }^{\text {, Ю. Ю. Лесишина }}{ }^{\text {a }, ~ М . ~ С . ~ Ф р а с и н ю к ~}{ }^{\text {b }, ~ О . ~ М . ~ Ш е н д р и к ~}{ }^{\text {a }}$ \\ а Донецький національний університет імені Василя Стуса, м. Вінниця, Україна \\ ${ }^{\mathrm{b}}$ Інститут біоорганічної хімії та нафтохімії НАН України, м. Київ, Україна
}

\begin{abstract}
Досліджено кінетику ферментативної реакції лакказного окиснення 7,8-дигідрокси-4-гідроксиметилкумарину, гідрохінону та кверцетину молекулярним киснем у сумішах води з диметилсульфоксидом (ДМСО) як добавки, що збільшує розчинність фенольних сполук. ДМСО дещо пригнічує активність лаккази, але не інгібує процес. 3 отриманих кінетичних даних випливає, що 7,8-дигідрокси-4-гідроксиметилкумарин, у порівнянні з гідрохіноном та кверцетином, є більш активним субстратом ферментативного відновлення молекулярного кисню. Це свідчить про перспективність використання похідних кумарину як сполук з потенційно високою медіаторною властивістю в реакціях переносу електрона на молекулярний кисень від молекул органічних субстратів.

Ключові слова: лакказа, ферментативне окиснення, медіатор, кумарин.
\end{abstract}

\section{Вступ}

Лакказа (КФ 1.10.3.2, пара-дифенол: кисень оксидоредуктаза) відноситься до класу мідьвмісних оксидаз і каталізує реакцію окиснення органічних і неорганічних сполук, в тому числі нефенольних ароматичних сполук 3 відносно низьким окисно-відновним потенціалом: орто-, пара-дифенолу, амінофенолів, поліфенолів, поліамінів, лігнінів, деяких неорганічних іонів 3 супутнім чотириелектронним відновленням молекулярного кисню до води, минаючи стадію утворення пероксиду водню [1-3]. Окиснення субстратів $\left(\mathrm{SH}_{2}\right)$ у присутності лаккази відбувається за наступною загальною схемою:

$$
\mathrm{SH}_{2}+{ }^{1} / 2 \mathrm{O}_{2} \stackrel{\text { лакказа }}{\longrightarrow} \mathrm{S}+\mathrm{H}_{2} \mathrm{O} \text {. }
$$

Більшість описаних до теперішнього часу лакказ були виділені з різних видів грибів, а також 3 рослин і мікроорганізмів та деяких комах $[4,5,6]$. Залежно від джерела ферменту i умов його виділення, субстратна специфічність і каталітична активність лаккази значно відрізняється [7].

Спектр субстратної специфічності лакказ може бути значно розширено за участю в реакції так званих редокс-медіаторів (пара лакказа/медіатор здатна окиснювати речовини 3 редокс-потенціалом, що перевищує 1100 мВ).
Редокс-медіатори $\epsilon$ низькомолекулярними субстратами лакказ, в результаті ферментативного окиснення яких утворюються високореакційні речовини, що здатні неферментативно окиснювати різні сполуки, які не є субстратами ферменту. Застосування медіаторів розкриває широкі можливості використання лаккази в розробці екологічно чистих технологій як для обробки i модифікації лігніновмісних матеріалів, так і для утилізації рослинних відходів (особливо для целюлозно паперової і текстильної промисловості) [8].

Незважаючи на більш ніж столітню історію дослідження лаккази, досі залишається актуальним пошук нових дешевих і доступних ефективних редокс-медіаторів лакказ. Як відомо, до одних із найефективніших редокс-медіаторів лакказ відносять заміщені феноли, до яких можна віднести і кумарини. Реакції окиснення кумаринів за участю лаккази досліджені в ряді публікацій. Авторами [9] вивчалась активність лаккази двох штамів Ganoderma lucidum - E47 i S - в реакції деградації лігніну в присутності іонів важких металів і фенольних сполук, в тому числі кумарину. Показано, що кращими індукторами лаккази штаму Ganoderma lucidum $\mathrm{S} \in$ йони міді та ферулова кислота, причому

* E-mail: a.tsyapalo@donnu.edu.ua

( ) К. М. Лаховець, О. С. Цяпало, Ю. О. Лесишина, М. С. Фрасинюк, О. М. Шендрик, 2017 
кумарин не виявляє властивостей індуктора; для лаккази штаму Ganoderma lucidum E47 здатність кумарину індукувати перебіг цієї реакції змінюється в ряду: фенол < кумарин $<$ ванілін < гваякол < ванілінова кислота < кумаринова кислота $<$ ферулова кислота.

В роботі [10] досліджена кінетика реакцій лакказного окиснення 2,2'-азино-біс(3-етилбензотіазолін-6-сульфонової кислоти (АБТС) і $L$-диоксифенілаланіну в присутності похідних кумарину. В результаті було встановлено, що 2-[(4-метил-2-оксо-2H-1-бензопіран-7-ил)окси]оцтова кислота спричиняє інгібуючий вплив на активність лаккази в реакції окиснення АБТС і не впливає на швидкість реакції окиснення $L$-диоксифенілаланіну.

Отже, літературні дані свідчать, що кумарин і його похідні можна використовувати в реакціях лакказного окиснення як субстрат, індуктор чи інгібітор окиснення фенольних сполук або ароматичних сполук нефенольного типу. Тому дослідження нових синтетичних похідних кумарину як субстрату для лаккази та можливості їх використання як медіатора є актуальними.

\section{Експериментальна частина}

Матеріали та реактиви: ферментний препарат лаккази Trametes versicolor («Sigma»); як субстрати лакказного окиснення використовували гідрохінон (ГХ); кверцетин; вперше синтезований 7,8-дигідрокси-4гідроксиметилкумарин (К).

Визначення кінетичних параметрів реакцій, каталізованих лакказою Trametes versicolor, - константи Міхаеліса $\left(K_{M}\right)$ і максимальної швидкості реакції $\left(V_{\text {макс }}\right)$ проводили за рівнянням Міхаеліса-Ментен. Кінетичні криві лінеаризували, використовуючи метод подвійних обернених величин (метод Лайнуївера-Берка). Кінетику реакцій вивчали спектрофотометричним методом на спектрофотометрі Specord 50 UV-VIS «Analytikjena», у термостатованій кюветі. Дослідження проводили в цитратній буферній (ЦБ) системі ( $\mathrm{pH} 4.5$ ) за температури $35 \pm 0.1{ }^{\circ} \mathrm{C}$. Враховуючи низьку розчинність фенолів у воді, експерименти проводили в бінарній суміші вода-диметилсульфоксид (ДМСО), з вмістом ДМСО від 2 до $20 \%$ за об’ємом ( $\varphi)$.

\section{Результати та їх обговорення}

Вплив вмісту ДМСО на активність лаккази. Відомо, що активність ферментів залежить від багатьох факторів: температури, $\mathrm{pH}$ середовища, наявності денатуруючих агентів, здатних змінювати конформацію ферменту i призводити до зміни конформації активного центру та зниження здатності взаємодіяти 3 субстратом [11].

ДМСО є розчинником для широкого кола органічних речовин, у тому числі біополімерів - пептидів, білків, нуклеїнових кислот, полісахаридів. Його вплив на активність ферментів досліджено недостатньо повно. Згідно одних літературних даних, в присутності високих концентрацій ДМСО (5 M) уреази, амілази, різні дегідрогенази і трансамінази інгібуються. 3 іншого боку, відомі ферменти, активність яких у присутності ДМСО, навпаки, зростає (наприклад, кисла гліцерофосфатаза) [11].

Для дослідження впливу вмісту ДМСО на активність лаккази попередньо були визначені кінетичні параметри реакції лакказного окиснення стандартного субстрату цього ферменту - гідрохінону (1,4-дигідроксибензолу) як за відсутності, так і за наявності ДМСО. На рис. 1 наведені початкові ділянки кінетичних кривих витрачання гідрохінону в реакції його лакказного окиснення молекулярним киснем у водному середовищі за означених умов. Тангенс кута нахилу початкової ділянки кінетичних кривих відповідає початковій швидкості цієї реакції. 3 рисунку видно, що додавання ДМСО зменшує швидкість реакції.

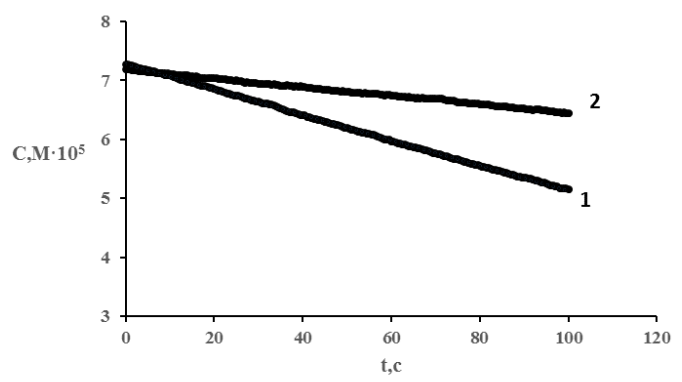

Рис. 1. Початкові ділянки кінетичних кривих витрачання гідрохінону в реакції лакказного окиснення молекулярним киснем $\left(C_{\Gamma \mathrm{X}}=0,6 \cdot 10^{-4} \mathrm{M}, C_{\text {лак }}=4 \mathrm{мг} / л\right)$ у ЦБ (pН 4.5), $T=35^{\circ} \mathrm{C}, \lambda=290 \mathrm{нм} ; 1-$ без ДМСО; $2-$ 3 додаванням ДМСО у кількості $10 \%$ (об.) 
Початкові швидкості реакції лакказного окиснення гідрохінону молекулярним киснем у водно-органічному середовищі були виміряні в сумішах води з ДМСО у кількості 2, 4, 10 і 20 \% (об.). Знайдені значення початкових швидкостей реакції були використані для графічного визначення $V_{\text {макс }}$ і $K_{M}$.

Залежність максимальної швидкості лакказного окиснення гідрохінону від складу бінарної суміші вода-ДМСО наведена на рис. 2.

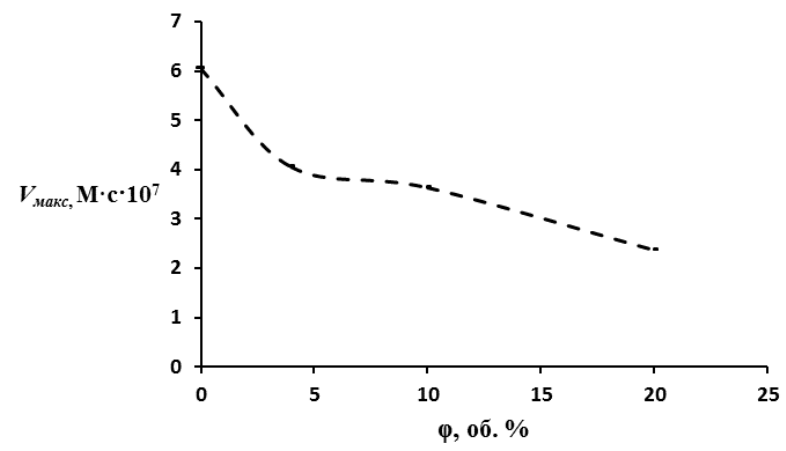

Рис. 2. Залежність максимальної швидкості лакказного окиснення гідрохінону в залежності від вмісту ДМСО у бінарній суміші з водою

Одержані результати свідчать, що додавання до реакційної суміші ДМСО зменшує швидкість ферментативної реакції, зокрема, за наявності $20 \%$ об. ДМСО - у 2 рази. Тому всі подальші дослідження кінетики реакції лакказного окиснення 7,8-дигідрокси4-гідроксиметилкумарину молекулярним киснем проводили у водно-органічному середовищі 3 мінімально можливим вмістом ДМСО - $2 \%$ (об.).

Кінетика реакиї лакказного окиснення 7,8-дигідрокси-4-гідроксиметилкумарину молекулярним киснем у водно-органічному середовищі. В УФ-видимому спектрі поглинання 7,8-дигідрокси-4-гідроксиметилкумарину $\epsilon$ дві смуги поглинання з максимумами при $\lambda=$ 260 нм та $\lambda=320$ нм. Характеристичність смуг поглинання похідних кумарину обумовлена хромофором, що включає пов'язані між собою $\alpha$-піронове і бензольне кільце.

В ході реакції ферментативного окиснення 7,8-дигідрокси-4-гідроксиметилкумарину у водно-органічному середовищі в УФспектрі положення й інтенсивність смуги поглинання при 260 нм за умов експерименту залишаються практично незмінними, а інтенсивність смуги з максимумом 320 нм поступово зменшується (рис. 3).

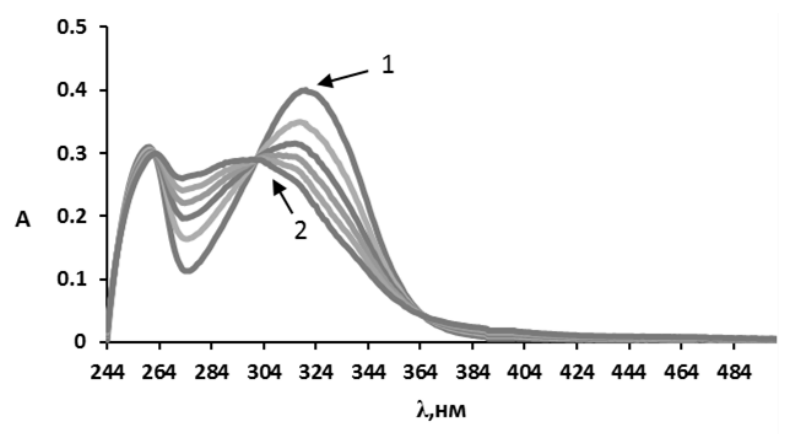

Рис. 3. Зміни абсорбційного спектру 7,8-дигідрокси-4-гідроксиметилкумарину при перебігу реакції його лакказного окиснення молекулярним киснем; $C_{\mathrm{K}}=1,6 \cdot 10^{-5} \mathrm{M}, C_{\text {лак }}=4$ мг/л, ЦБ ( $\left.\mathrm{pH} 4.5\right)$, вміст ДМСО - $2 \%$ (об.), $T=35^{\circ} \mathrm{C}$; крива 1 відповідає початку реакції, крива 2 - через 5 хвилин

Визначення кінетичних параметрів реакції лакказного окиснення 7,8-дигідрокси4-гідроксиметилкумарину молекулярним киснем у водно-органічному середовищі проводили проводили в подальшому при 320 нм. Значення молярного коефіцієнта абсорбції 7,8-дигідрокси-4-гідроксиметилкумарину $\mathrm{y}$ цитратній буферній системі ( $\mathrm{pH} 4.5)$ з вмістом ДМСО $2 \%$ (об.) при довжині хвилі 320 нм дорівнює $9698.5 \mathrm{M}^{-1} \cdot \mathrm{cM}^{-1}$.

Значення $V_{\text {макс }}$ і $K_{M}$ реакції знаходили графічним методом за рівнянням ЛайнуівераБерка (рис. 4).

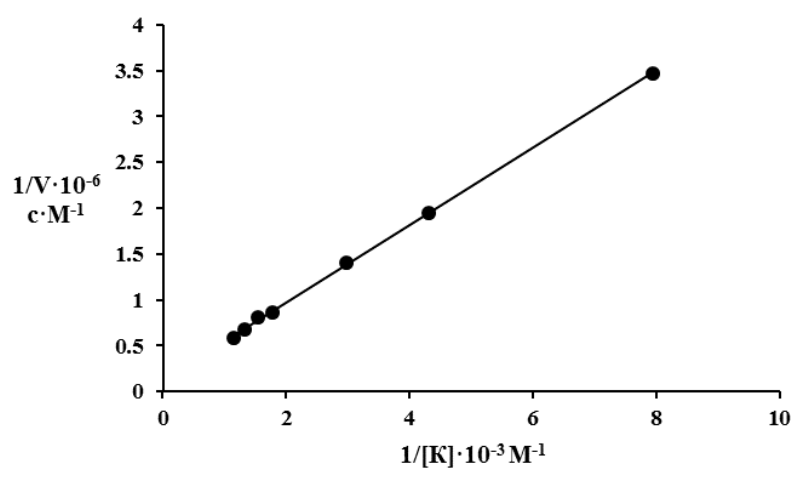

Рис. 4. Залежність початкової швидкості реакції лакказного окиснення 7,8-дигідрокси-4-гідроксиметилкумарину молекулярним киснем від концентрації кумарину у координатах рівняння ЛайнуівераБерка. $\quad C_{\text {лак }}=4$ мг/л, $\quad C_{\mathrm{K}}=1 \cdot 10^{-5}-8 \cdot 10^{-5} \mathrm{M}, \quad$ ЦБ $\mathrm{pH}=4.5$; вміст ДМСО $-2 \%$ (об.), $T=35^{\circ} \mathrm{C}$ 
Розраховані величини $V_{\text {макс }}$ і $K_{M}$ дорівнюють $6.42 \cdot 10^{-7} \mathrm{M} \cdot \mathrm{c}^{-1}$ та $2.69 \cdot 10^{-4} \mathrm{M}$, відповідно.

Для порівняльної характеристики окиснювальної здатності 7,8-дигідрокси4-гідроксиметилкумарину як субстрату лаккази були визначенні кінетичні параметри реакції лакказного окиснення флавоноїду кверцетину, який широко застосовується як антиоксидант в харчовій і фармацевтичній промисловості.

Згідно з літературними даними [12], в УФ-видимому спектрі кверцетину є дві смуги поглинання з максимумами при 260 і 370 нм, які в результаті його окиснення зникають. Тому кінетику реакції лакказного окиснення флавоноїду молекулярним киснем у водноорганічному середовищі досліджували за витрачанням кверцетину при 370 нм. Молярний коефіцієнт поглинання кверцетину при цій довжині хвилі дорівнює $22000 \mathrm{M}^{-1} \cdot \mathrm{cm}^{-1}$ [13].

Кінетичні параметри реакції лакказного окиснення фенольних сполук за однакових умов наведено в Табл. 1.

Табл. 1. Кінетичні параметри лакказного окиснення при наявності різних субстратів

\begin{tabular}{|c|c|c|}
\hline Субстрат & $V_{\text {макс }} \cdot 10^{-7}, \mathrm{M} \cdot \mathrm{c}^{-1}$ & $K_{M} \cdot 10^{-4}, \mathrm{M}$ \\
\hline Кверцетин & 4.51 & 1.23 \\
\hline Гідрохінон & 6.04 & 2.21 \\
\hline $\begin{array}{l}\text { 7,8-Дигідрокси-4-гід- } \\
\text { роксиметилкумарин }\end{array}$ & 6.42 & 2.69 \\
\hline
\end{tabular}

Результати свідчать, що всі досліджені феноли ефективно окиснюються в присутності лаккази Trametes versicolor, причому найбільша активність лаккази спостерігається саме по відношенню до 7,8-дигідрокси-4-гідроксиметилкумарину. Це може бути обумовлено як структурними особливостями кумарину, так і його електронно-донорними властивостями.

\section{Висновки}

Встановлено, що 7,8-дигідрокси4-гідроксиметилкумарин проявляє найбільшу реакційну здатність серед вивчених фенолів у каталізованій лакказою Trametes versicolor реакції відновлення молекулярного кисню. Показано, що вміст диметилсульфоксиду в реакційній суміші пригальмовує процес лак- казного окиснення, але не інгібує його повністю. Одержані результати свідчать про перспективність використання похідних кумарину як сполук 3 потенційно високою медіаторною властивістю, а також про можливість застосування добавок ДМСО для підвищення розчинності субстратів лаккази.

\section{Подяка}

Робота виконана за фінансової підтримки МОН України в рамках держбюджетних тем «Лакказо-медіаторні окиснювальні системи» (№ держреєстрації 0114U003515) і «Протонспряжений перенос електрона в гомолітичних реакціях фенолів у водних і водно-органічних середовищах» (№ держреєстрації 0117U002361).

\section{Перелік посилань}

1. Solomon E. I., Sundaram U. M., Machonkin T. E. Multicopper Oxidases and Oxygenases. ChemInform. 1996, 96(7), P. 2563-2606.

2. Boyer P. D. The Enzymes. Academic Press 1981, $641 \mathrm{p}$.

3. Yaropolov A.I., Skorobogat'ko O.V., Vartanov S.S. and Varfolomeyev S.D. Laccase: Properties, catalytic mechanism, and applicability. Applied Biochemistry and Biotechnology 1994, 49(3), P. 257-280.

4. Ranocha P., Mcdougall G., Hawkins S. et al. Biochemical characterization, molecular cloning and expression of laccases - a divergent gene family - in poplar. European Journal of Biochemistry 1999, 259(1-2), P. 485-495.

5. Ryan S., Schnitzhofer W., Tzanov T., CavacoPaulo A., Gübitz G. An acid-stable laccase from Sclerotium rolfsii with potential for wool dye decolourization. Enzyme and Microbial Technology 2003, 33(6), P. 766-774.

6. Hall M., Scott T., Sugumaran M., Soderhall K., Law J. H. Proenzyme of Manduca sexta phenol oxidase: purification, activation, substrate specificity of the active enzyme, and molecular cloning. Proceedings of the $\mathrm{Na}$ tional Academy of Sciences. 1995. 92(17). P. 7764-7768.

7. Mogharabi M.; Faramarzi M. A. Laccase and Laccase-Mediated Systems in the Synthesis of Organic Compounds. ChemInform. 2014. 45(23).

8. Изучение ферментативной активности грибов P. Aspergillius при культивировании на растительных отходах. Прутенская Е.А., Степанов А.В., Сульман Э.М. II Московский международный Конгресс: Биотехнология: состояние и перспективы развития. Москва, 2003. Часть 2. - С. 38.

9. Kuhar F.; Papinutti L. Optimization of laccase production by two strains of Ganoderma lucidum using phenolic and metallic inducers. Revista Argentina de Microbiología. 2014, 46(2), P. 144-149.

10. Tisma M.; Molnar M.; Skarica M.; Cacic M.; Zelic B. Laccase Inhibiting Activity of Some Coumarin 
Вісник Донецького національного університету імені Василя Стуса. Сер. хімічні науки. № 1, 2017

Derivatives. Letters in Organic Chemistry. 2014. 11(8). P. 583-589.

11. Martin D.; Hauthel H. G. Dimethylsulphoxid. Akademie-Verlag, Berlin, 1971

12. Биорадикалы и биоантиоксиданты: монография. Костюк В.А., Потапович А.И. Минск, 2004. 174 с.

13. Lee K.-M.; Kang H.-S.; Yun C.-H.; Kwak H.-S. Potential in vitro Protective Effect of Quercetin, Catechin,
Caffeic Acid and Phytic Acid against Ethanol-Induced Oxidative Stress in SK-Hep-1 Cells. Biomolecules and Therapeutics 2012, 20(5), P. 492-498.

Рукопис надійшов до редакиії 15.05.2017

УДК 577.152.113

Катализируемое лакказой Trametes versicolor окисление 7,8-дигидрокси-4-гидроксиметилкумарина

К. М. Лаховец, А. С. Цяпало, Ю. О. Лесишина, М. С. Фрасинюк, А. Н. Шендрик

Исследована кинетика ферментативной реакции лакказного окисления 7,8-дигидрокси-4-гидроксиметилкумарина, гидрохинона и кверцетина молекулярным кислородом в смесях воды с диметилсульфоксидом (ДМСО) как добавки, которая увеличивает растворимость фенольных соединений. ДМСО несколько подавляет активность лакказы, но не ингибирует процесс. Из полученных кинетических данных следует, что 7,8-дигидрокси4-гидроксиметилкумарин, в сравнении с гидрохиноном и кверцетином, является более активным субстратом ферментативного восстановления молекулярного кислорода. Это свидетельствует о перспективности использования производных кумарина в роли соединений с потенциально высокими медиаторными свойствами в реакциях переноса электрона на молекулярный кислород с молекул органических субстратов.

Ключевые слова: лакказа, ферментативное окисление, медиатор, кумарин.

Catalyzed by Laccase from Trametes versicolor oxidation of 7,8-dihydroxy-4-hydroxymethyl coumarin

K. M. Lakhovets a, O. S. Tsyapalo a , Yu. O. Lesishina ${ }^{\text {a }}$, M. S. Frasinjuk ${ }^{\text {b }}$, O. M. Shendrik ${ }^{\text {a }}$

a Department of Biochemistry and Physical Chemistry, Vasyl' Stus Donetsk National University, Vinnytsya, Ukraine

${ }^{b}$ Institute of Bioorganic Chemistry and Petrochemistry of the National Academy of Sciences of Ukraine, Kyiv, Ukraine

The kinetics of the reaction of laccase oxidation of 7,8-dihydroxy-4-hydroxymethylcoumarin, hydroquinone and flavonoide quercetin with molecular oxygen in an aqueous-organic medium was studied. The influence of the content of dimethylsulfoxide on the activity of laccase from Trametes versicolor in the reaction of enzymatic oxidation of phenols with molecular oxygen was established. Analysis of the kinetic data of laccase oxidation of phenolic compounds under the experimental conditions allows to conclude that 7,8-dihydroxy-4-hydroxymethylcoumarin is a more reactive phenol compared to the standard substrate of laccase hydroquinone and flavonoid quercetin. This indicates the prospectivity of studying coumarin derivatives as compounds with potentially high mediator properties.

Keywords: laccase, enzymatic oxidation, mediator, coumarin.

References

1. Solomon, E. I.; Sundaram, U. M.; Machonkin, T. E. Multicopper Oxidases and Oxygenases. ChemInform 1996, 28(10), 2563 DOI: 10.1002/chin.199710268.

2. Boyer, P. D. The Enzymes; Academic Press: New York, 1981.

3. Yaropolov, A. I.; Skorobogat'ko, O. V.; Vartanov, S. S.; Varfolomeyev, S. D. Laccase. Applied Biochemistry and Biotechnology 1994, 49 (3), 257-280 DOI: 10.1007/bf02783061.

4. Ranocha, P.; Mcdougall, G.; Hawkins, S.; Sterjiades, R.; Borderies, G.; Stewart, D.; Cabanes-Macheteau, M.; Boudet, A.-M.; Goffner, D. Biochemical characterization, molecular cloning and expression of laccases - a divergent gene family - in poplar. European Journal of Biochemistry 1999, 259(1-2), 485-495 DOI: 10.1046/j.14321327.1999.00061.x.

5. Ryan, S.; Schnitzhofer, W.; Tzanov, T.; Cavaco-Paulo, A.; Gübitz, G. An acid-stable laccase from Sclerotium rolfsii with potential for wool dye decolourization. Enzyme and Microbial Technology 2003, 33(6), $766-774$ DOI: 10.1016/s0141-0229(03)00162-5.

6. Hall, M.; Scott, T.; Sugumaran, M.; Soderhall, K.; Law, J. H. Proenzyme of Manduca sexta phenol oxidase: purification, activation, substrate specificity of the active enzyme, and molecular cloning. Proceedings of the National Academy of Sciences 1995, 92(17), 7764-7768 DOI: 10.1073/pnas.92.17.7764.

7. Mogharabi, M.; Faramarzi, M. A. Laccase and Laccase-Mediated Systems in the Synthesis of Organic Compounds. ChemInform 2014, 45(23) DOI: 10.1002/chin.201423258.

8. Prutenskaia, E. A.; Stepanov, A. V.; Sulman, E. M. Izuchenie fermentativnoi aktivnosti gribov P. Aspergillius pri kultivirovanii na rastitelnykh otkhodakh. [A study of the enzymatic activity of $P$. Aspergillius fungi in cultivation on plant waste]. In II Moskovskii mezhdunarodnyi Kongress: Biotekhnologiia: sostoianie i perspektivy razvitiia. Materialy kongressa. Part 2; 2003; p. 38. (In Russian)

9. Kuhar, F.; Papinutti, L. Optimization of laccase production by two strains of Ganoderma lucidum using phenolic and metallic inducers. Revista Argentina de Microbiología 2014, 46(2), 144-149 DOI: 10.1016/s0325-7541(14)70063-X.

10. Tisma, M.; Molnar, M.; Skarica, M.; Cacic, M.; Zelic, B. Laccase Inhibiting Activity of Some Coumarin Derivatives. Letters in Organic Chemistry 2014, 11(8), 583-589 DOI: 10.2174/157017861108140613161919. 
Вісник Донецького національного університету імені Василя Стуса. Сер. хімічні науки. № 1, 2017

11. Martin, D.; Hauthel, H. G. Dimethylsulphoxid. Akademie-Verlag, Berlin, 1971.

12. Kostiuk, V. A.; Potapovich, A. I. Bioradikaly i bioantioksidanty: monografiia. [Bioradicals and bioantioxidants: monograph.] Minsk, 2004. (In Russian)

13. Lee, K.-M.; Kang, H.-S.; Yun, C.-H.; Kwak, H.-S. Potential in vitro Protective Effect of Quercetin, Catechin, Caffeic Acid and Phytic Acid against Ethanol-Induced Oxidative Stress in SK-Hep-1 Cells. Biomolecules and Therapeutics 2012, 20(5), 492-498 DOI: 10.4062/biomolther.2012.20.5.492. 